\title{
A Survey on the Demotivation in English Learning Among Chinese Rural Middle School Students
}

\author{
Gengchun Li \\ School of Foreign Languages, Taizhou University, Taizhou, P. R. China
}

\section{Email address:}

charlietjut@163.com

\section{To cite this article:}

Gengchun Li. A Survey on the Demotivation in English Learning Among Chinese Rural Middle School Students. International Journal of Applied Linguistics and Translation. Vol. 5, No. 4, 2019, pp. 72-77. doi: 10.11648/j.ijalt.20190504.14

Received: October 13, 2019; Accepted: November 7, 2019; Published: November 14, 2019

\begin{abstract}
Demotivation, as an emerging field of study, has received increasing attention in recent years. It has been found by many Chinese researchers that various demotivators, both external and internal, could lead to students' decrease of motivation in learning English as a foreign language (EFL). A less researched area, however, is the demotivators in the EFL learning of Chinese rural middle school students, who account for a large proportion of the student population in middle schools in China. In the present research study, a total of 99 students in a rural middle school in Yancheng, China were randomly selected as respondents, among whom a questionnaire survey was conducted on their EFL learning motivation and demotivation. It is found by a factor analysis that the biggest factor contributing to the demotivation of these students in English learning is the lack of interest in learning, among other internal and external factors, such as decline in self-confidence, poor learning abilities, lack of learning strategies, difficulty of textbook articles, and rare use of multi-media in English classes. No significant differences were found between male and female students in their English learning demotivation. This study not only duplicates the results of previous studies, but also puts forward constructive suggestions to eliminate the phenomenon of demotivation in English learning in rural middle schools in China.
\end{abstract}

Keywords: English Learning, Demotivation, Demotivators, Rural Junior Middle School

\section{Definition of Demotivation}

According to Dornyei, motivation research in the past has typically conceptualized a 'motive' as a kind of 'inducement', that is, as a force whose strength ranges on a continuum from zero to strong, without much being said about 'negative' motives [1]. However, there is no denying that the other side of motivation, i.e. demotivation, has long been neglected.

Until now, demotivation is still a relatively new concept that has not yet been fully explored in the field of second language acquisition (SLA) or foreign language learning (FLL). According to Dornyei, demotivating factors refer to "specific external forces that reduce or diminish the motivational basis of a behavioral intention or an ongoing action."[1] p.143 'Demotivation' and 'demotives' are the negative counterparts of 'motivation' and 'motives' respectively. A motive increases the tendency of an action while a demotive decreases it. A learner who is demotivated is someone who was initially motivated in learning but has lost his or her motivation due to certain external negative factors somewhere in later stages of learning. Demotivation can be triggered by various factors. For example, previous unpleasant learning experiences or boring lectures given by teachers may be possible sources of demotivation for learners. In Dornyei's view, demotivation starts mainly from external triggers and motivation must exist before a subsequent decrease or loss. However, some researchers [2-6] pointed out that not only external factors but also internal factors could be sources of demotivation. The problem with the definition of demotivation, therefore, is that it has not yet been empirically determined whether demotivating factors are completely external or not.

\section{Previous Studies on Demotivation in FLL}

Generally, discussion of the factors affecting demotivation is mainly concentrated on four levels: social environment, learning situations, situational activities, and learners. On the level of social environment, studies have shown that the 
conception of education and the values of foreign language education of the whole society, and family background, etc. are important factors that influence learners' demotivation for FLL [7-8]. On the level of learning situation, imperfect teaching conditions, such as excessive class size and poor qualifications of teachers, are important incentives for demotivation $[1,6]$. On the level of situational activities, teachers' teaching methods, teaching styles, teaching abilities, teachers' personalities, teacher-student relationships and peer relationships are the main causes for students' lack of motivation in FLL [9]. On the level of learners, lack of inherent interest and self-confidence [9], negative ideas in English learning [8], etc. also have an important influence on students' demotivation in FLL.

In China, from 2009 to 2018, research articles published on Chinese core journals and CSSCI (Chinese Social Science Citation Index) journals totalled 27, with 6 articles published in 2013 and 2015, respectively. Upon closer examination, research on demotivation in FLL in China in the past decade can be divided into three stages: 1) initial stage (2009 -- 2011), with only one article published; 2) development stage (2012 -2016), with 22 articles published; 3) declining stage (2017 -2018), with 4 articles published. On the whole, there are relatively fewer research articles related to demotivation in FLL in China, averaging no more than 3 per year. What's more, there has been ups and downs in the number of studies in this emerging research area.

Among the 27 articles, there are 18 articles whose theme is influencing factors for demotivation in FFL. Zhou \& Wang [10], Tang [11] and Sun \& Lei [12] explored the factors that trigger college students' demotivation in FFL, and found that external factors including teachers and their teaching methods, teaching conditions, courses and textbooks, etc. are the main causes for demotivation in FFL. Y. Yu [13] and $\mathrm{Su}$ [14] investigated the influencing factors in the decline of FLL motivation among distance learners, and found that internal factors like insufficient language aptitude, lack of interest, and lack of FFL strategies, etc. contribute to the demotivation among this group of learners. W-Q. Yu [15], C-L. Li [16] and P. Li [17] conducted empirical studies on the factors of demotivation among international students in China, senior middle school students, and military school students, respectively. A comprehensive analysis showed that the factors that trigger demotivation include both internal and external factors. The internal factors include insufficient language aptitude, lack of inherent interest, lack of effective learning strategies, decline in self-confidence, insufficient affective-cognitive abilities, etc. The external factors are comprised of teachers' personalities and teaching abilities, teaching styles, teaching environment, and courses and textbooks, etc. Clearly, it is shown by these studies that there are multiple factors in students' FFL demotivation.

Overall, compared with foreign countries, research on demotivation in FLL in China started later, and most of the studies are based on college students, and only a couple of studies on the demotivation of English learners in primary and secondary schools have been conducted. Currently, the only demotivation study among rural junior middle school students in China is that of Li Chili in 2016 [18]. And that study was done 3 years ago. Therefore, the author once again intends to explore the factors that influence the demotivation of FFL among rural junior middle school students to verify the results of $\mathrm{Li}$ [18] on the one hand, and provides suggestions for eliminating demotivating factors among these students on the other.

\section{The Present Study}

One of the author's students once worked as a student-teacher in a rural junior middle school for 4 months. During the internship, he found that more than half of the students in the school were not interested in learning English. Compared with urban students in the same area, rural students generally have poor English proficiency and lower abilities in English oral expression. Therefore, the author decided to conduct a survey to reveal the factors of demotivation in FFL among this group of students.

\subsection{Research Questions}

The author intends to explore the factors affecting the demotivation of FFL among rural middle school students and find answers to the following questions:

1) What are the demotivating factors in English learning for students in rural junior middle schools in China?

2) Are there any differences in demotivation between male and female students?

3) What are the ways to eliminate the demotivating factors for rural middle school students in English learning in China?

\subsection{Research Design}

\subsubsection{Subjects}

The subjects of this study are 99 students from a rural junior middle school in Yancheng, Jiangsu Province. The scores of the Senior Middle School Entrance Examination of this school are on an average level in this area, which means the school chosen for this study is fairly representative of schools of its kind in this city. A total of 39 boys and 60 girls were surveyed. The youngest is 11 years of age and the oldest 15 , with an average age of 13.65. The maximum period for studying English is 9 years, the minimum 4 years, and the average English learning period is 4.66 years. Participants were randomly selected from parallel classes in the first grade to the third grade, and their English scores varied.

Table 1. Information of the subjects.

\begin{tabular}{llllll}
\hline & Gender & \multicolumn{5}{c}{ Grade } \\
\cline { 2 - 6 } & male & female & Grade 1 & Grade 2 & Grade 3 \\
\hline The number & 39 & 60 & 33 & 33 & 33 \\
The proportion & $39.39 \%$ & $60.61 \%$ & $33.3 \%$ & $33.3 \%$ & $33.3 \%$ \\
\hline
\end{tabular}

\subsubsection{Instrument}

A questionnaire was used to collect data. In designing the questionnaire, the author referred to the questionnaire used by 
Ye Nan [19] and the research by Li Chili [18]. Before preparing the formal questionnaire, the author conducted a random interview with 20 students of the school and administered a pre-test of the questionnaire to preliminarily understand the state of the respondents' demotivation in English learning, and identify possible demotivating factors for these students.

The formal questionnaire consists of three parts. The first part is to gather some basic information about the students, including grade, gender and years spent on learning English; the second part consists of 8 questions to probe into the students' learning motivation; and the third part explores the factors that weaken students' learning motivation. Items of the questionnaire cover both internal factors and external ones. The former include interest in learning, learning strategies, self-confidence, affective and cognitive abilities, and learning experiences. The latter include teacher ability and style, curriculum and learning materials, teaching facilities, and peer influence. A total of 24 statements are included in the questionnaire, which adopts the Likert scale. Subjects are asked to choose the most suitable option from the five options of "completely inconsistent", "usually inconsistent", "uncertain", "largely consistent" and "completely consistent", based on their understanding of the relevant statement.

Analysis shows that the overall reliability of the questionnaire was 0.837 (Cronbach $\alpha$ ), with the second and third part being 0.792 and 0.892 respectively, indicating that the questionnaire has acceptable reliability.

\subsection{Research Procedure}

\subsubsection{Data Collection}

The survey was conducted in a rural junior middle school in Yancheng, Jiangsu Province, where one of the author's students worked as a student teacher. Data collection was started on November 30, 2018 and lasted for three days. The author and other English teachers of the participating classes explained the concepts of English learning motivation and demotivation to the students before school was over on Friday, 30th. Then, the link of the questionnaire was shared in each class' QQ group. Students were asked to use their free time on weekends to finish the questionnaire independently without discussing with each other.

A total of 100 students participated in the survey, and one unqualified questionnaire was excluded. A total of 99 questionnaires were collected, and the recovery rate was 99\%.

\subsubsection{Data Analysis}

In this study, the social statistics software SPSS 21.0 was used to analyze the results of the questionnaire. The main statistical methods include descriptive statistics and factor analysis.

\section{Results and Discussion}

From the results of the second part of the questionnaire, it can be seen that most students have strong motivation to learn. A total of 64 students, accounting for $64.65 \%$ of the total, hope to learn English well, and 58 of them, taking up 58.59\%, have made a lot of efforts to improve their English. Seen from the other perspective, 35 students do not have strong motivation to learn English well, and 41 students have not made much effort to improve their English.

For the third part of the questionnaire, the author first analyzed whether the data is suitable for factor analysis. As can be seen from Table 2, KMO is 0.843 , greater than 0.6 , meeting the precondition of factor analysis, which means that the data can be used for factor analysis.

Table 2. Validity Analysis.

\begin{tabular}{ll}
\hline KMO & 0.843 \\
Bart sphere & 1150.087 \\
$d f$ & 276 \\
$p$ & 0.000 \\
\hline
\end{tabular}

The data was further tested by Bartlett's sphericity test $(p<0.05)$, indicating again that the data is suitable for factor analysis. And then the data was rotated using the varimax method to find the corresponding relationship between the factors and the questionnaire items. A total of 5 factors were obtained (see Table 3), and the cumulative variance explained was $61.57 \%$.

Table 3 shows that the current demotivating factors for English learning among these students are as follows: poor learning abilities, lack of learning strategies, lack of self-confidence, lack of interest in learning, and improper teaching materials and learning environment. Among them, the first four factors are related to individual learner factors and are internal factors; the last factor, improper teaching materials and learning environment, is an external factor.

Table 3. Factor Loading Coefficients.

\begin{tabular}{|c|c|c|c|c|c|}
\hline \multirow{3}{*}{ Questionnaire item } & \multicolumn{5}{|c|}{ Factor loadings } \\
\hline & Factor 1 & Factor 2 & Factor 3 & Factor 4 & Factor 5 \\
\hline & $\begin{array}{l}\text { Learning } \\
\text { abilities }\end{array}$ & $\begin{array}{l}\text { Learning } \\
\text { interest }\end{array}$ & $\begin{array}{l}\text { Teaching materials \& } \\
\text { learning environment }\end{array}$ & $\begin{array}{l}\text { Learning } \\
\text { strategies }\end{array}$ & $\begin{array}{l}\text { Self- } \\
\text { confidence }\end{array}$ \\
\hline I don't know the purpose of learning English. & & 0.649 & & & \\
\hline I'm not personally interested in English language and culture. & & 0.427 & & & \\
\hline I'm not interested in the topics of texts in the coursebook. & & 0.418 & & & \\
\hline I have difficulties in memorizing English words and phrases. & 0.615 & & & & \\
\hline $\begin{array}{l}\text { I didn't learn English pronunication well, and I did poorly in } \\
\text { English listening and speaking. }\end{array}$ & 0.592 & & & & \\
\hline Someone once laughed at me for my poor English. & & & & & 0.772 \\
\hline The articles in the coursebook are very long, with many new & & & 0.731 & & \\
\hline
\end{tabular}




\begin{tabular}{|c|c|c|c|c|c|}
\hline \multirow{3}{*}{ Questionnaire item } & \multicolumn{5}{|c|}{ Factor loadings } \\
\hline & Factor 1 & Factor 2 & Factor 3 & Factor 4 & Factor 5 \\
\hline & $\begin{array}{l}\text { Learning } \\
\text { abilities }\end{array}$ & $\begin{array}{l}\text { Learning } \\
\text { interest }\end{array}$ & $\begin{array}{l}\text { Teaching materials \& } \\
\text { learning environment }\end{array}$ & $\begin{array}{l}\text { Learning } \\
\text { strategies }\end{array}$ & $\begin{array}{l}\text { Self- } \\
\text { confidence }\end{array}$ \\
\hline \multicolumn{6}{|l|}{ words. } \\
\hline $\begin{array}{l}\text { Arranging seats according to scores on tests demotivated me to } \\
\text { learn. }\end{array}$ & & 0.638 & & & \\
\hline Learning English is too difficult, so I don't want to learn it. & & 0.647 & & & \\
\hline $\begin{array}{l}\text { I'd take the initiative to analyse the cause (s) for my declining } \\
\text { performance on English tests. }\end{array}$ & & & & -0.875 & \\
\hline I'd be happy to ask my teacher when I meet difficulties. & & & & -0.85 & \\
\hline $\begin{array}{l}\text { I wouldn't get praise from my teachers and parents if I made } \\
\text { progress in my study. }\end{array}$ & & & & & 0.679 \\
\hline My classmates would laught at me for my poor English. & & & & & 0.645 \\
\hline I once made a fool of myself in English class. & & & & & 0.52 \\
\hline My teachers are too serious, so I do not like English class. & & 0.624 & & & \\
\hline $\begin{array}{l}\text { My teachers would show favouritism to students with good } \\
\text { grades. }\end{array}$ & & 0.463 & & & \\
\hline $\begin{array}{l}\text { The classes of the English teacher are too boring, not so } \\
\text { interesting as the classes of other teachers. }\end{array}$ & & 0.615 & & & \\
\hline $\begin{array}{l}\text { The projector in the classroom does not work well. The } \\
\text { projected images are blurred, and it is often diffcult to see them } \\
\text { clearly. }\end{array}$ & & & 0.509 & & \\
\hline $\begin{array}{l}\text { The classroom is overcrowded with students, with sultry air and } \\
\text { often bad smells. }\end{array}$ & & & 0.585 & & \\
\hline Multi-media devices are seldom used in English classes. & & & 0.658 & & \\
\hline $\begin{array}{l}\text { My parents are always chattering about the importance of } \\
\text { learning English, which results in my antipathy against English } \\
\text { learning. }\end{array}$ & & 0.528 & & & \\
\hline $\begin{array}{l}\text { English is too important for me, which even makes me very } \\
\text { anxious. }\end{array}$ & & & & & 0.788 \\
\hline $\begin{array}{l}\text { All of my classmates don't like learning English, so I don't like } \\
\text { learning English either. }\end{array}$ & & 0.709 & & & \\
\hline
\end{tabular}

Among the five factors obtained by varimax, factor 2 "learning interest" contains 6 items with loadings over 0.60. It involves negative influence from peers (0.709), indeterminate purpose in learning English (0.649), the perceived difficulty in learning English (0.647), improper arrangement of seats according to scores on tests $(0.638)$, teacher being too serious (0.624), and classes being too boring (0.615). Lack of interest in learning is the biggest demotivating factor.

Factor 5 "self-confidence" contains 4 items with loadings over 0.60 . This indicates that students lose confidence due to excessive emphasis on English learning (0.788), unpleasant learning experience of being laughed at by classmates and others due to poor mastery of English $(0.645,0.772)$, and failure to get praise from parents and teachers for progress made in learning English (0.679).

Factor 3 "teaching materials and learning environment" contains 2 items with loadings over 0.60 , involving the difficulty of textbook articles (0.731), and rare use of multi-media in English classes (0.658).

Factor 1 "learning ability" also contains 2 items with loadings exceeding 0.60 , involving difficulty in memorizing English words and phrases (0.615), and bad scores on previous English tests (0.702).

Analysis of the last factor "learning strategies" indicates that quite a number of students do not know how to solve the problems existing in the process of English learning, and only 43 students $(43.43 \%)$ would consult their teachers when they encountered difficulties in the process of learning.

According to the results of the questionnaire, lack of interest in learning has become the biggest demotivating factor for rural middle school students. Secondly, other internal factors like decline in confidence (5 items with loadings over 0.5), poor learning abilities (3 items with loadings over 0.5 ), and lack of learning strategies (2 items with loadings over 0.5 ) make it difficult for many students to improve their English despite their high enthusiasm for learning. At the same time, external factors also affect students' English learning negatively, such as the textbook articles being too long with many new words, too little use of multi-media in English classes, the class being oversized, and poor effect of projectors. These internal and external factors would act on the students simultaneously making them demotivated to a great extent.

To answer the second question raised by the present study, a T-test analysis was conducted of the demotivating factors for male and female students, which does not show any significant differences. Therefore, demotivation in FFL among these students does not seem to be affected by students's gender. 
Table 4. Results of the T-test.

\begin{tabular}{|c|c|c|c|c|}
\hline \multirow{2}{*}{ Questionnaire item } & \multicolumn{2}{|c|}{ Gender $(M \pm$ S.D. $)$} & \multirow{2}{*}{$\mathbf{t}$} & \multirow{2}{*}{$p$} \\
\hline & Male $(\mathbf{N}=39)$ & Female $(N=60)$ & & \\
\hline I don't know the purpose of learning English. & $2.44 \pm 1.33$ & $2.53 \pm 1.19$ & -0.38 & 0.705 \\
\hline I'm not personally interested in English language and culture. & $2.49 \pm 1.37$ & $2.60 \pm 1.36$ & -0.402 & 0.688 \\
\hline I'm not interested in the topics of texts in the coursebook. & $2.56 \pm 1.33$ & $2.58 \pm 1.17$ & -0.076 & 0.94 \\
\hline I have difficulties in memorizing English words and phrases. & $2.49 \pm 1.37$ & $2.85 \pm 1.33$ & -1.312 & 0.193 \\
\hline I used to have bad grades on English tests. & $2.44 \pm 1.35$ & $2.87 \pm 1.31$ & -1.58 & 0.117 \\
\hline $\begin{array}{l}\text { I didn't learn English pronunication well, and I did poorly in English listening and } \\
\text { speaking. }\end{array}$ & $2.77 \pm 1.33$ & $2.82 \pm 1.36$ & -0.171 & 0.864 \\
\hline Someone once laughed at me for my poor English. & $2.49 \pm 1.23$ & $2.45 \pm 1.28$ & 0.143 & 0.886 \\
\hline The articles in the coursebook are very long, with many new words. & $2.95 \pm 1.34$ & $2.97 \pm 1.30$ & -0.066 & 0.947 \\
\hline Arranging seats according to scores in tests demotivated me to learn. & $2.67 \pm 1.46$ & $2.75 \pm 1.42$ & -0.282 & 0.778 \\
\hline Learning English is too difficult, so I don't want to learn it. & $2.51 \pm 1.43$ & $2.55 \pm 1.29$ & -0.134 & 0.894 \\
\hline $\begin{array}{l}\text { I'd take the initiative to analyse the cause (s) for my declining performance on English } \\
\text { tests. }\end{array}$ & $3.31 \pm 1.49$ & $3.22 \pm 1.21$ & 0.334 & 0.739 \\
\hline I'd be happy to ask my teacher when I meet difficulties. & $3.31 \pm 1.44$ & $3.30 \pm 1.17$ & 0.029 & 0.977 \\
\hline I wouldn't get praise from my teachers and parents if I made progress in my study. & $2.64 \pm 1.37$ & $2.42 \pm 1.15$ & 0.878 & 0.382 \\
\hline My classmates would laught at me for my poor English. & $2.28 \pm 1.34$ & $2.02 \pm 1.08$ & 1.086 & 0.28 \\
\hline I once made a fool of myself in English class. & $2.74 \pm 1.41$ & $2.57 \pm 1.23$ & 0.661 & 0.51 \\
\hline My teachers are too serious, so I do not like English class. & $2.44 \pm 1.37$ & $2.52 \pm 1.19$ & -0.311 & 0.756 \\
\hline My teachers would show favouritism to students with good grades. & $2.82 \pm 1.48$ & $3.07 \pm 1.33$ & -0.861 & 0.391 \\
\hline $\begin{array}{l}\text { The classes of the English teacher are too boring, not so interesting as the classes of } \\
\text { other teachers. }\end{array}$ & $2.62 \pm 1.41$ & $2.60 \pm 1.32$ & 0.055 & 0.956 \\
\hline $\begin{array}{l}\text { The projector in the classroom does not work well. The projected images are blurred, } \\
\text { and it is often diffcult to see them clearly. }\end{array}$ & $2.31 \pm 1.30$ & $2.73 \pm 1.26$ & -1.621 & 0.108 \\
\hline The classroom is overcrowded with students, with sultry air and often bad smells. & $3.00 \pm 1.38$ & $3.03 \pm 1.22$ & -0.126 & 0.9 \\
\hline Multi-media devices are seldom used in English classes. & $2.26 \pm 1.23$ & $2.55 \pm 1.35$ & -1.097 & 0.275 \\
\hline $\begin{array}{l}\text { My parents are always chattering about the importance of learning English, which } \\
\text { results in my antipathy against English learning. }\end{array}$ & $2.33 \pm 1.32$ & $2.52 \pm 1.32$ & -0.674 & 0.502 \\
\hline English is too important for me, which even makes me very anxious. & $2.54 \pm 1.33$ & $2.70 \pm 1.14$ & -0.644 & 0.521 \\
\hline $\begin{array}{l}\text { All of my classmates don't like learning English, so I don't like learning English } \\
\text { either. }\end{array}$ & $2.15 \pm 1.29$ & $2.22 \pm 1.14$ & -0.255 & 0.799 \\
\hline
\end{tabular}

\section{Conclusion}

\subsection{Major Findings of the Present Study}

This study takes rural junior middle school students as the research subjects, in order to explore the demotivating factors in their English learning, possible differences between male and female students in this regard, and the ways to eliminate these demotivating factors. The author conducted a survey among 99 students in the rural middle school where one of the author's students worked as an internship teacher for four months. The survey found that students in rural junior middle schools have commonly experienced demotivation in their English learning. This conclusion is consistent with that of $\mathrm{Li}$ [18]. Among the various factors that contribute to students' demotivation for English learning, the lack of interest in learning has become a major factor. Other internal factors, such as decline in self-confidence, poor learning abilities, and lack of learning strategies also have a great impact on demotivation among these students in English learning, and this is also consistent with the view of Li [18]. Finally, the demotivation for male and female students was analyzed by a T-test, and no significant differences were found.

\subsection{Suggestions for Stakeholders}

\subsubsection{Suggestions for Teachers and Schools}

Based on the results of the survey, English teachers in rurual junior middle schools should use multi-media devices in their teaching more often, and they should adopt effective teaching methods to make their classes more interactive and interesting Being strict with students is a good thing, but being too serious in class may distance teachers away from the students. Therefore, it is of high necessity for English teachers in these schools to build a pleasant and harmonious relationship with the students. In this regard, using more positive verbal evaluation of students for their performance in activities may be a good start to build this relationship one one hand and to promote students' motivation to learn more on the other. The schools should improve the teaching environment as much as possible, clean the classroom in time and reduce the class size.

\subsubsection{Suggestions for Textbook Designers}

As for the textbook designers, they should consider the basic differences between urban and rural junior middle school students and design multi-level textbooks as far as possible to meet the differing needs of urban and rural students.

\subsubsection{Suggestions for Parents}

Parents should evaluate their children's learning attitude and performance in school correctly, rather than taking their scores on tests as the only criterion to judge whether their children study hard or not. At the same time, parents should not overemphasize the importance of English learning, causing their children to be rebellious. Finally, parents should expose students to English as much as possible in their spare 
time, such as watching English movies and reading books in both Chinese and English versions.

\subsubsection{Suggestions for Students}

Junior middle school students in rural areas should first treat English learning correctly. They should realize that English is as important as any other subject taught in school. To learn English well, they should equip themselves with appropriate and effective learning strategies, and ask their English teachers for help as often as possible to remove the barriers to their English learning. More importantly, they should not lose confidence in English learning just because they fall behind temporarily.

\section{References}

[1] Dörnyei, Z. Teaching and Researching Motivation [M]. Harlow, UK: Longman, 2001.

[2] Arai, K. What 'demotivates' language learners?: Qualitative study on demotivational factors and learners' reactions [J]. Bulletin of Toyo Gakuen University, 2004 (12): 39-47.

[3] Kojima, S. English Learning Demotivation in Japanese EFL Students: Research in Demotivational Patterns from the Qualitative Research Results of Three Different Types of High Schools [D]. Hyogo, Japan: Kwansei Gakuin University, 2004.

[4] Falout, J. \& M. Maruyama A comparative study of proficiency and learner demotivation [J]. The Language Teacher, 2004, 28: 3-9.

[5] Falout, J. \& M. Falout. The other side of motivation: Learner demotivation [A]. In K. Bradford-Watts et al. (Eds.), JALT 2004 Conference Proceedings [C]. Tokyo: Jalt, 2005: 280-89.

[6] Sakai, H. \& K. Kikuchi. An analysis of demotivates in the EFL classroom [J]. System, 2009, 37 (1): 57-69.

[7] Kim, T. Y. \& H. S. Seo. Elementary school students' foreign language learning demotivation: A mixed methods study of Korean EFL context [J]. The Asia-Pacific Education Researcher, 2012, 21 (1): 160-171.
[8] Lamb, M. "Your mum and dad can't teach you!": Constraints on agency among rural learners of English in the developing world. Journal of Multilingual and Multicultural Development, 2013, 34 (1): 14-29.

[9] Hamada, Y. Different demotivators for Japanese junior high school learners [J]. Journal of Pan-Pacific Association of Applied Linguistics, 2011, 15 (1): 15-38.

[10] Zhou, C-B. \& W-B. Wang. Demotivators analysis of Chinese university EFL learners [J]. Foreign Languages in China, 2012, 9 (1): 48-55.

[11] Tang, W-L. An analysis of demotivators in non-English major college students' English learning [J]. Foreign Language Education, 2012, 33 (1): 70-75.

[12] Sun, Y-M \& L. Lei. An analysis of demotivators in Chinese college EFL classrooms [J]. Foreign Languages Research, 2013, (5): 57-65.

[13] Yu, Y. Research on the demotivators of English learners in distance network education and coping strategies [J]. China Educational Technology, 2012 (9): 48-53.

[14] $\mathrm{Su}, \mathrm{Q}$. A study on demotivation and motivational regulation of distance foreign language learners [J]. Foreign Language World, 2015 (2): 53-60.

[15] Yu, W-Q. An analysis of factors effecting demotivation of foreign students' Chinese learning [J]. Language Teaching and Linguistic Studies, 2013 (3): 24-31.

[16] Li, C-L. Empirical study on negative motivation in English learning by senior secondary school pupils: Based on group interviews [J]. Teaching \& Administration, 2015 (36): 20-23.

[17] Li, P. Police learners' demotivation to study police English [J]. Foreign Language and Literature, 2015, 31 (2): 144-150.

[18] Li, C-L. An empirical study on the demotivators in rural middle school learners' English learning [J]. Basic Foreign Language Education, 2016, 18 (2): 13-17.

[19] Ye, N. A Study on Demotivation of High School EFL Learners [D]. Unpublished master thesis. Hangzhou: Zhejiang University, 2018. 